\title{
31. DINOFLAGELLATE CYST STRATIGRAPHY OF THE LOWER CRETACEOUS SEQUENCE AT SITES 762 AND 763, EXMOUTH PLATEAU, NORTHWEST AUSTRALIA ${ }^{1}$
}

\author{
Wolfram Brenner ${ }^{2}$
}

\begin{abstract}
Cores from Leg 122, Sites 762 and 763, were sampled at intervals of one sample per 1.5-m section in the Lower Cretaceous sequences. More than 400 samples were studied, most of which contained dinoflagellate cysts, spores, pollen, and various types of palynoclasts. From the entire palynomorph assemblage mainly dinoflagellate cysts were studied to give a stratigraphic outline for the Lower Cretaceous. Stratigraphic units were interpreted in terms of zones in use for the Jurassic and Cretaceous of Australia.

At both sites a condensed Valanginian to Aptian sequence and an expanded middle to late Berriasian sequence containing a rich microplankton assemblage were recovered. Sites 762 and 763 can be correlated with each other and with the wells Eendracht-1 and Vinck-1.
\end{abstract}

\section{INTRODUCTION}

During Leg 122 of the Ocean Drilling Program (ODP), six holes were drilled at two sites (Sites 762 and 763) on the central Exmouth Plateau (Fig. 1). The objective of Leg 122 was to study the rift, breakup, and paleoenvironmental, stratigraphic, and geodynamic evolution from "juvenile" to "mature" oceanic stages along a continental margin.

From the Exmouth Plateau, Lower Cretaceous dinoflagellate cysts were previously recovered from petroleum exploration wells and described by Stevens (1987), Stevens and Helby (1987), and Stover and Helby (1987a, 1987b). Helby et al. (1987) erected a "standard dinoflagellate zones" for the Australian Mesozoic, while Ingram and Morgan (1988) reviewed the development and status of Mesozoic palynostratigraphy of the Australian Northwest Shelf. This paper reports the first results of the palynological studies in the Lower Cretaceous sediments of Sites 762 and 763. Taxonomic and palynofacies discussion, and a complete description of the dinoflagellate cyst assemblages, will be given elsewhere.

\section{METHODS}

During Leg 122, shipboard palynological studies were attempted from about 100 samples of the Lower Cretaceous sediments to outline a dinoflagellate zonation by correlation with zonations described for the Cretaceous of northwest Australia (Helby et al., 1987). Onboard laboratory processing facilities precluded routine use of hydrofluoric acid (HF). The technique used on the ship (Haq, von Rad, O'Connell, et al., 1990) yields only a partial assemblage of the entire palynomorph content of the sediment and is not usable for quantitative examinations. Thus, the shipboard samples/slides are not taken into account for onshore studies.

All the samples were given a standard palynological processing treatment: after cleaning and drying $20 \mathrm{~g}$ of the sample were boiled in $35 \%$ hydrochloric acid $(\mathrm{HCl})$ and then washed with water through a $10-\mu \mathrm{m}$ sieve. The residue was processed with $\mathrm{HF}$ and washed again through a $10-\mu \mathrm{m}$ sieve. From the remains a small quantity for fluorescence and scanning slides

\footnotetext{
${ }^{1}$ von Rad, U., Haq, B. U., et al., 1992. Proc. ODP, Sci. Results, 122: College Station, TX (Ocean Drilling Program).

${ }^{2}$ GEOMAR, Wischhofstr. 1-3, 2300 Kiel 14, Federal Republic of Germany.
}

was removed. The rest was oxidized with $60 \%$ nitric acid $\left(\mathrm{HNO}_{3}\right)$ to remove pyrite and amorphous organic debris. Slides were made with the mounting media Entellan.

\section{PALYNOSTRATIGRAPHY}

The dinoflagellate zonation used in this paper is based on the biostratigraphic subdivisions of Helby et al., 1987 (Fig. 2). The age assignment to these zones is based mainly on tentative correlations with European dinoflagellate sequences. For example, one of the best known palyno-events that has been documented from both Europe and Australia is the extinction horizon near the Berriasian-Valanginian boundary. It is marked by the extinction of Egmontodinium torynum, many of the typical Upper Jurassic lineages, and the first occurrence of the Spiniferites ramosus Group and many species of the Muderongia Group (Davey, 1979; Heilmann-Clausen, 1987; Helby et al., 1987; Rawson and Riley, 1982; Woollam and Riding, 1983).

\section{Palynomorphs at Site 762}

Muderongia australis Zone (2dii to 2diii); Samples 122$762 \mathrm{C}-79 \mathrm{X}-1,14-17 \mathrm{~cm}$, through $122-762 \mathrm{C}-79 \mathrm{X}-\mathrm{CC}, 35-38 \mathrm{~cm}$; suggested age: uppermost Hauterivian to Barremian.

This interval consists of hemipelagic black to grey calcareous claystone and contains a predominantly moderatelypreserved dinoflagellate suite. Spores and pollen are nearly absent (less than $0.5 \%$ ) and plant debris (wood fragments and cuticles) are essentially absent. The interval from Samples $122-762 \mathrm{C}-79 \mathrm{X}-1,14-17 \mathrm{~cm}$, through $122-762 \mathrm{C}-79 \mathrm{X}-3,90-93$ $\mathrm{cm}$, contains the typical dinoflagellate assemblage of the Muderongia australis Zone, which gives a uppermost Hauterivian to Barremian age (Fig. 3).

Muderongia testudinaria Zone (2div); Sample 122-762C$80 \mathrm{X}-\mathrm{CC}$; suggested age: Hauterivian.

The poor recovery (less than 1\%) allows us to use only the shipboard sample of the core catcher for stratigraphic dating. However, the presence of Dingodinium cerviculum, with a total range from the base of the Muderongia testudinaria Zone to the middle of the Muderongia tetracantha Zone, and $\mathrm{Mu}$ derongia testudinaria, with a last occurrence on top of the Muderongia testudinaria Zone, suggests the Muderongia testudinaria dinoflagellate Zone (2div), which is Hauterivian in age.

Egmontodinium torynum to Dissimulidinium lobispinosum Zones (4ai-ii to $4 \mathrm{bi}$ ); Samples $122-762 \mathrm{C}-81 \mathrm{X}-1,47-50 \mathrm{~cm}$, 


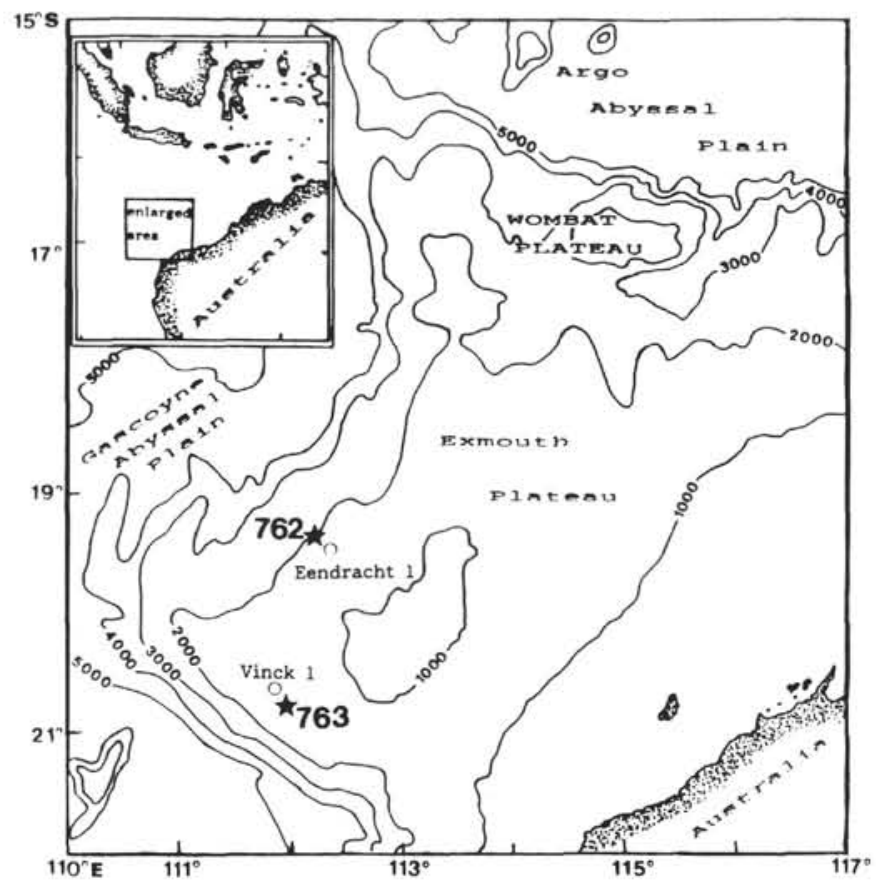

Figure 1. Bathymetric map (in meters) of the Australian Northwest Shelf region showing location of ODP sites on the Exmouth Plateau.

through 122-762C-91X-02, 15-17 cm; suggested age: (middle-) late Berriasian to earliest Valanginian.

This interval consists of black to dark grey silty claystone and clayey siltstone. The palynomorph preservation ranges from poor to moderate; pollen and plant debris dominate most samples. Sample 122-762C-81X-1, 47-50 cm, contains Egmontodinium torynum and Systematophora areolata in relatively high abundance. This indicates the Egmontodinium torynum acme, which occurs at the top of the Egmontodinium torynum Zone (4ai). Sample 122-762C-81X-1, 112$115 \mathrm{~cm}$, contains only a few, poorly preserved dinoflagellates, making it difficult to assign this sample to a specific zone.

Batioladinium reticulatum to Dissimulidinium lobispinosum Zone (4aiii-4bi); Samples 122-762C-81X-2, 50-54 cm, through 122-762C-91X-CC; suggested age: middle to late Berriasian.

The Batioladinium reticulatum Zone is defined by the range of the eponymous species, with the highest occurrence at Sample 122-762C-81X-22, 50-54 cm, and the lowest occurrence at Sample $122-762 \mathrm{C}-86 \mathrm{X}-4,18-20 \mathrm{~cm}$. The highest occurrence of Dissimulidinium lobispinosum was recorded in Sample 122-762C-86X-1, $112-115 \mathrm{~cm}$. Based on the first occurrence of these dinoflagellate cysts, the interval between these samples could be assigned to the upper part of the Batioladinium reticulatum Zone (4aiii).

However, Samples 122-762C-87X-1, 115-118 cm, and 122 $762 \mathrm{C}-88 \mathrm{X}-1,19-21 \mathrm{~cm}$, contain only a few, poorly preserved dinoflagellate cysts. Thus, the true last downhole occurrence of Batioladinium reticulatum cannot be assigned. Nevertheless, on the basis of the occurrence of the dinoflagellate cysts the interval from Samples 122-762C-81X-02, 50-54 cm, through $122-762 \mathrm{C}-85 \mathrm{X}-2,35-37 \mathrm{~cm}$, can be assigned to the upper Batioladinium reticulatum Zone (4aiii), and the interval from Samples 122-762C-86X-1, $112-115 \mathrm{~cm}$, through 122 $762 \mathrm{C}-86 \mathrm{X}-4,18-20 \mathrm{~cm}$, to the lower Batioladinium reticulatum Zone (4aiv). The continuous presence of Dissimulidinium lobispinosum in the interval from Sample 122-762C-88X-2, $116-119 \mathrm{~cm}$, to the bottom of the hole points to the Dissimulidinium lobispinosum Zone (4bi).

\section{Palynomorphs at Site $\mathbf{7 6 3}$}

Sections 122-763B-2X-CC through 122-763B-24X-CC and Core $122-763 \mathrm{C}-2 \mathrm{R}$. This interval consists of pelagic nannofossil and foraminifer chalk and ooze and all core-catcher samples analyzed on board from this interval are barren of palynomorphs. In Hole $763 \mathrm{C}$ a single core (Core $122-763 \mathrm{C}-2 \mathrm{R}$ ) was taken in this interval around the Cenomanian-Turonian boundary. This core overlaps Cores 122-763B-23X and 122763B-24X.

Sample $122-763 \mathrm{C}-2 \mathrm{X}-1,17-19 \mathrm{~cm}$, contains only a few acritarchs with no stratigraphic significance. Sample 122$763 \mathrm{C}-2 \mathrm{X}-1,26-29 \mathrm{~cm}$, contains a few specimens assigned to Ascodinium, Isabelidinium, and Dinogymnium. The occurrence of very few specimen of the Dinogymnium group suggests a Turonian age or younger; however, R. Helby (pers. comm., 1990) reported very small forms of Dinogymnium from northwest Australia from the Diconodinium multispinum Zone (Cenomanian). Therefore, this sample is questionably assigned to the Turonian.

Samples $122-763 C-2 X-1,41-43 \mathrm{~cm}, 122-763 \mathrm{C}-2 \mathrm{X}-1,59-61$ $\mathrm{cm}$, and $122-763 \mathrm{C}-2 \mathrm{X}-1,66-68 \mathrm{~cm}$, contain few dinoflagellate cysts and those present are mostly poorly preserved and fragmented. Fluorescence data suggest that some of the dinoflagellate cyst fragments are reworked. The presence of well-preserved Ascodinium parvum in these samples points to a late Albian to Cenomanian.

Samples $122-763 \mathrm{~B}-25 \mathrm{X}-1,48-50 \mathrm{~cm}$, through $122-763 \mathrm{~B}-$ $38 \mathrm{X}$-CC. Most of the 70 samples in this interval are barren of palynomorphs. Only some samples contain dinoflagellate cysts (most less than one dinoflagellate cyst per gram of sediment). Therefore, a clear dinoflagellate zonation cannot be assigned to this interval and the samples are not mentioned in the range chart for Hole 763B (Fig. 4). Nevertheless, the few dinoflagellate cysts presented suggest an Albian to Cenomanian age for this interval.

Samples 122-763B-39X-1, 47-50 cm, through 122-763B$40 \mathrm{X}-2,50-53 \mathrm{~cm}$. In this interval Circulodinium colliveri is the most dominant dinoflagellate cyst with an abundance of over 99\% from the whole palynomorph assemblage (Fig. 4). Helby et al. (1987) reported that this species can be a prominent form in the Diconodinium davidii Zone (2biii). However, the absolute dominance of one species points to an extreme environment and may not be necessarily age significant. Therefore, this interval is questionably correlated with the late Aptian Diconodinium davidii Zone (2biii).

Odontochitina operculata Zone (2c); Sample 122-763B$41 \mathrm{X}-1,47-49 \mathrm{~cm}$, through $122-763 \mathrm{~B}-42 \mathrm{X}-4,45-49 \mathrm{~cm}$; suggested age: early Aptian. This interval contains a small number of predominantly poorly to moderately preserved dinoflagellate cysts. However, the presence of Muderongia australis at the top and Muderongia macwhaei at the base of this interval point to the Odontochitina operculata Zone (2c).

Except for very rare bisaccate pollen no terrestrial palynomorphs, plant debris, and foram-liners were found in and above Sample 122-763B-42X-3, 44-50 cm.

Muderongia australis to Operculodinium operculata Zone (2c to 2dii); Samples 122-763B-42X-5, 46-51 cm, through 122-763B-43X-1, 44-47 cm; suggested age: late Barremian to early Aptian. The palynomorph assemblage in this interval contains sparse, poorly to moderately well-preserved dinoflagellate cysts without stratigraphic significance. Therefore, this interval is regarded as transitional between the Zones 2c/2dii. 


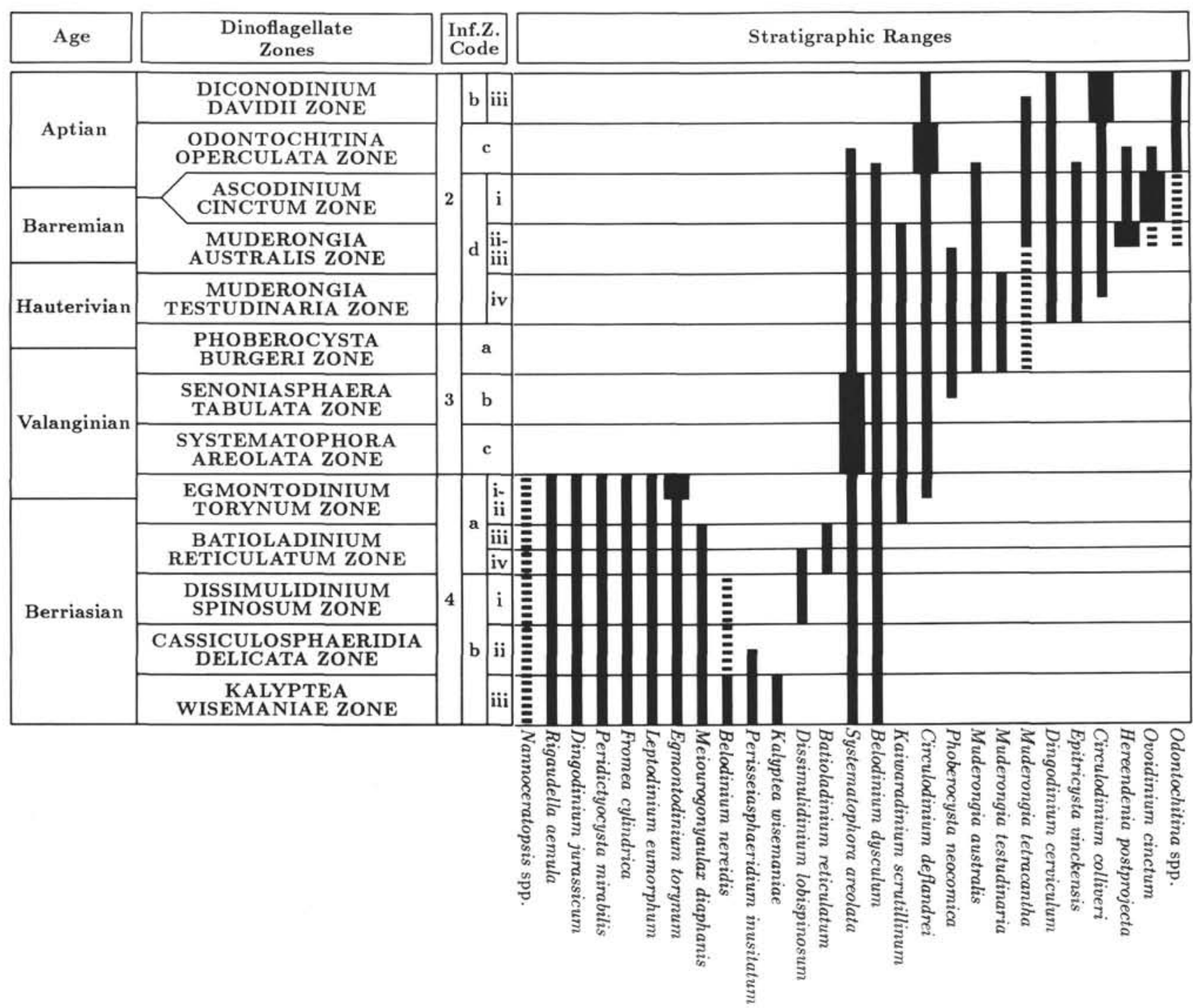

Figure 2. Dinoflagellate zones and stratigraphic ranges of dinoflagellate cyst index species (adapted from Helby et al., 1987). Wide lines $=$ prominent; narrow lines $=$ consistent; and stripes $=$ inconsistent.

Muderongia australis Zone (2dii/2diii); Samples 122-763B$43 \mathrm{X}-3,48-50 \mathrm{~cm}$, through 122-763B-46X-5, 45-49 cm; suggested age: uppermost Hauterivian to late Barremian. The sediments of this interval contain a dinoflagellate cyst assemblage, which is typical for the Muderongia australis Zone. Spores, pollen, and plant debris are sporadically a common element of this interval.

Muderongia testudinaria Zone (2div); Samples 122-763B$46 \mathrm{X}-6,44-48 \mathrm{~cm}$, through 122-763B-47X-CC, 46-49 cm; suggested age: middle to late Hauterivian. The base of this interval (Sample 122-763B-47X-CC, $46-49 \mathrm{~cm}$ ) is marked by the oldest occurrence of Dingodinium cerviculum. The occurrence of this form, together with a relatively diverse muderongoid suite, is characteristic of the Muderongia testudinaria Zone.

Systematophora areolata to Phoberocysta burgeri Zone (3a to 3c); Samples 122-763B-48X-1, 108-111 cm, through 122-763B-48X-4, 50-53 cm; suggested age: middle Valanginian to early Hauterivian. Most of the age-significant species are absent from this interval; therefore, a clear zonation cannot be given. However, the consistent presence of Systematophora areolata suggests that this interval belongs to the
Systematophora areolata Zone (3a) rather than to the Senoniasphaera tabulata Zone (3b) or Phoberocysta burgeri Zone $(3 \mathrm{c})$. Furthermore, there is a significant downhole increase of plant debris, which points to an environmental change and that the composition of the dinoflagellate assemblage may be overprinted by ecological factors.

Egmontodinium torynum Zone (4ai-ii); Sample 122-763B$48 \mathrm{X}-5,48-52 \mathrm{~cm}$; suggested age: late Berriasian to lowermost Valanginian. Sample 122-763B-48X-5, 48-52 cm, contains a dinoflagellate cyst assemblage, which is typical for the $E g$ montodinium torynum Zone. All other samples from Samples 122-763B-48X-5, 48-52 cm, through 122-763B-49X-4, 46-48 $\mathrm{cm}$, contain occasional, predominantly poorly preserved dinoflagellate cysts. Terrestrial palynomorphs and plant debris dominate all samples.

Batioladinium reticulatum Zone (4aiii to 4aiv); Samples 122-763B-50X-1, 48-51 cm, to $122-763 \mathrm{~B}-54 \mathrm{X}-\mathrm{CC}$ and $122-$ 763C-6R-1, 46-49 cm, through 122-763C-21R-3, 47-55 cm; suggested age: late Berriasian. The first downhole occurrence of Batioladinium reticulatum is in Sample 122-763B-50X-1, 48-51 cm (Fig. 4), and of Dissimulidinium lobispinosum in Sample 122-763C-10R-3, 107-109 cm (Fig. 5). The last down- 


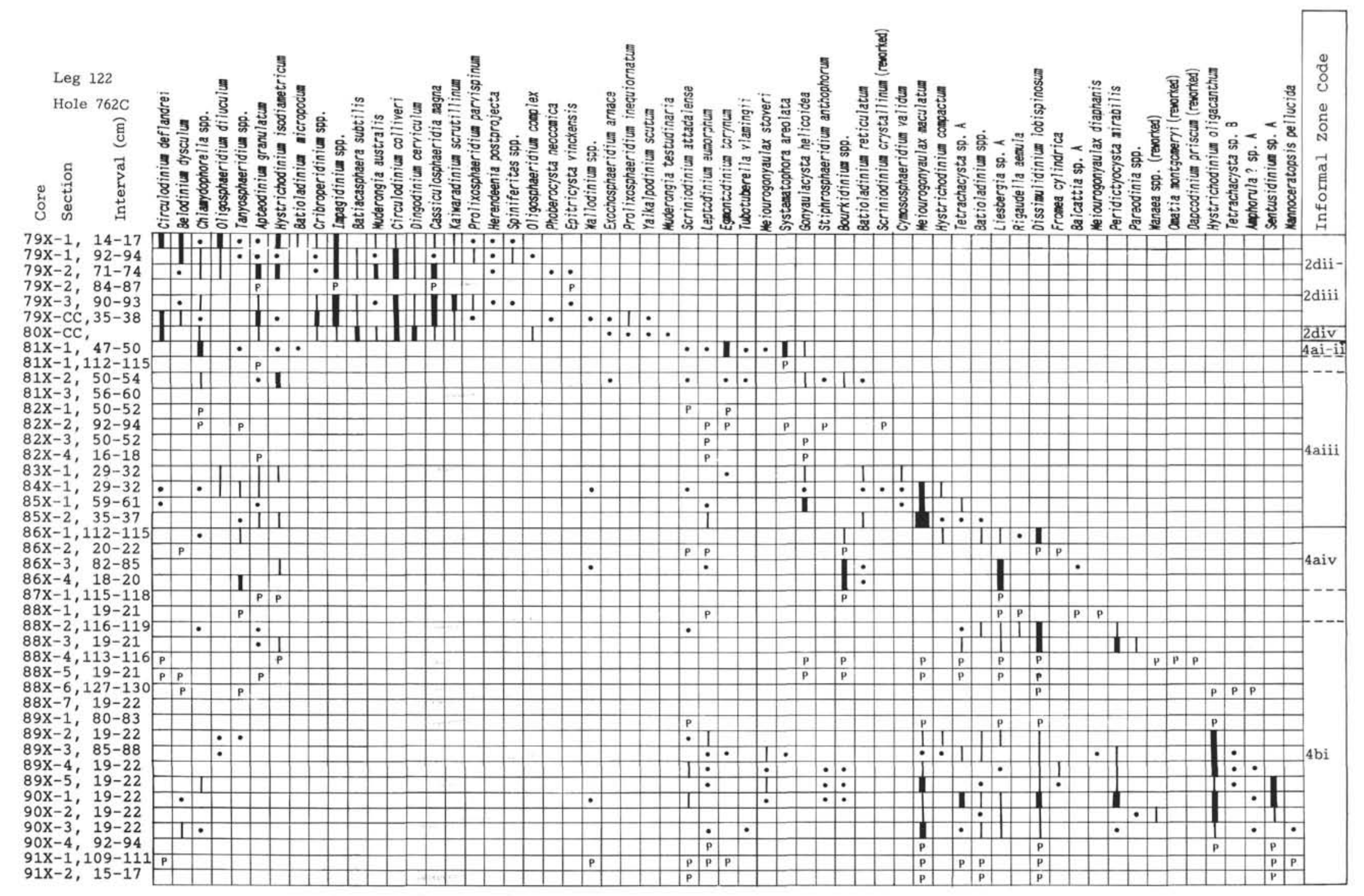

Figure 3. Range charts of selected dinoflagellate cysts in Hole $762 \mathrm{C}$. Points $=$ rare; small lines $=$ few; medium lines $=$ common; thick lines $=$ abundant; and $P=$ species are present but bad preservation and/or a small number of palynomorphs reflect only a selective assemblage. 


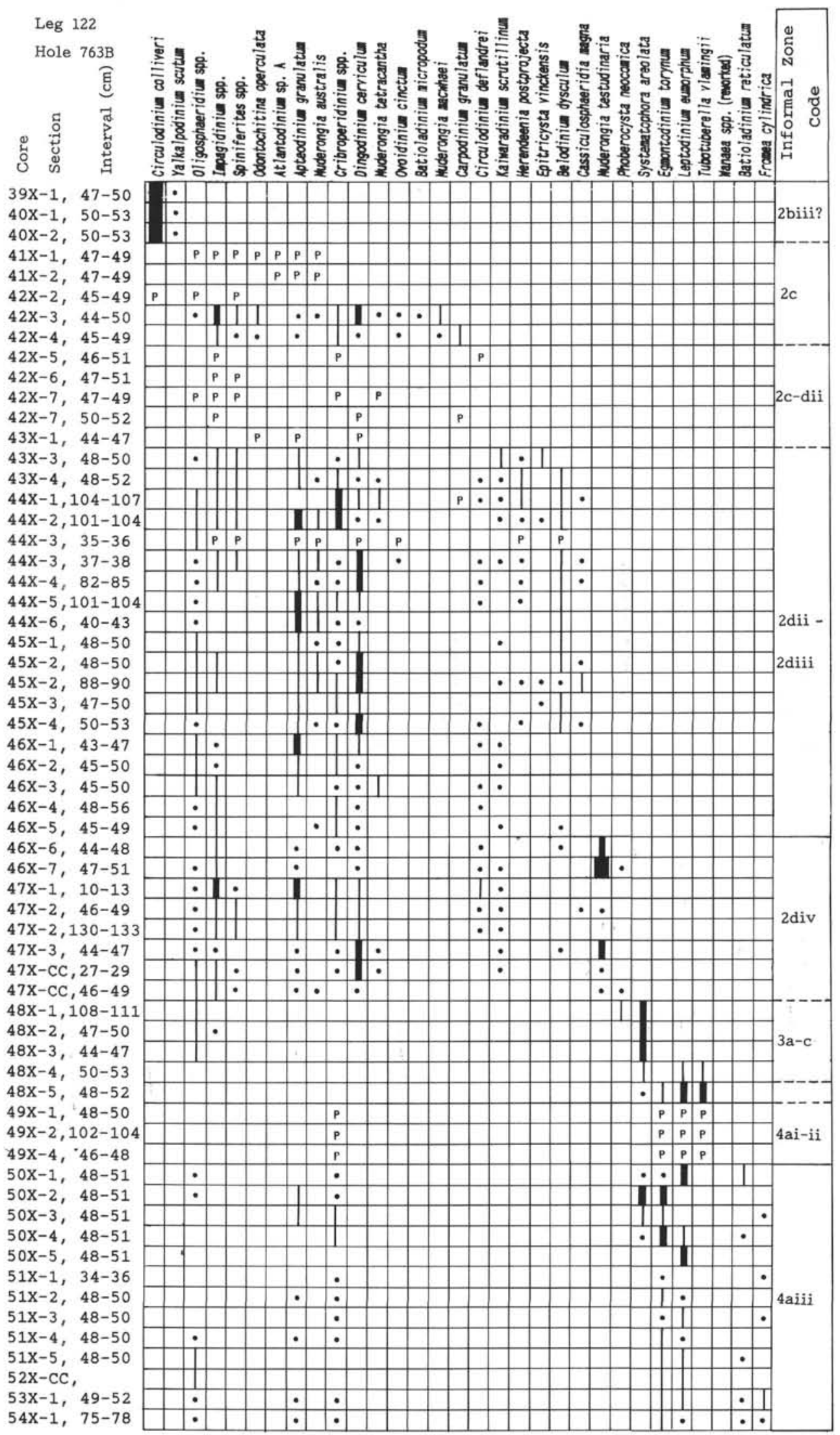

Figure 4. Range charts of selected dinoflagellate cysts in Hole 763B. Points = rare; small lines $=$ few; medium lines = common; thick lines $=$ abundant; and $\mathrm{P}=$ species are present but bad preservation and/or a small number of palynomorphs reflect only a selective assemblage. 


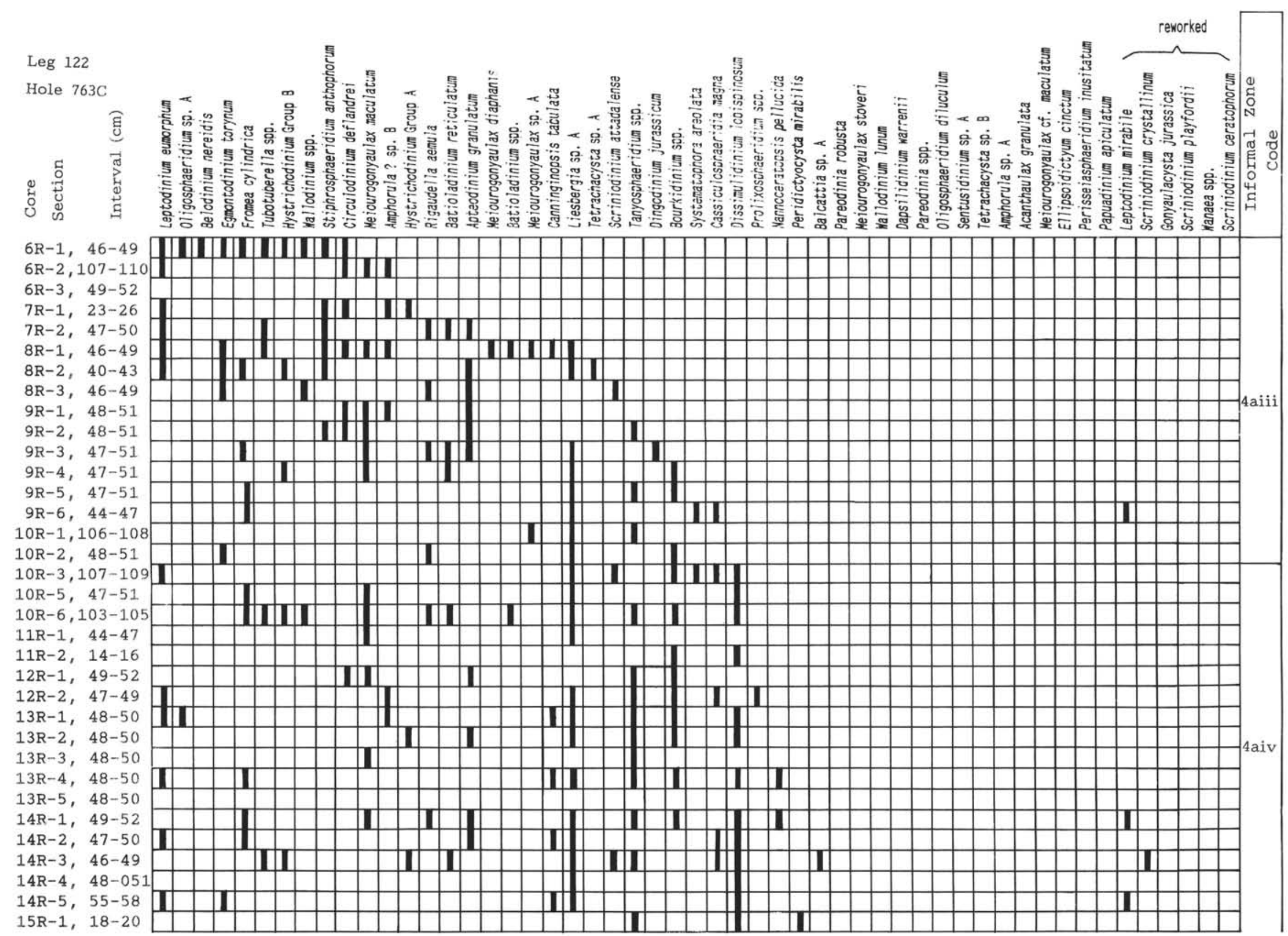

Figure 5. Present/not present range charts of selected dinoflagellate cysts in Hole $763 \mathrm{C}$. 


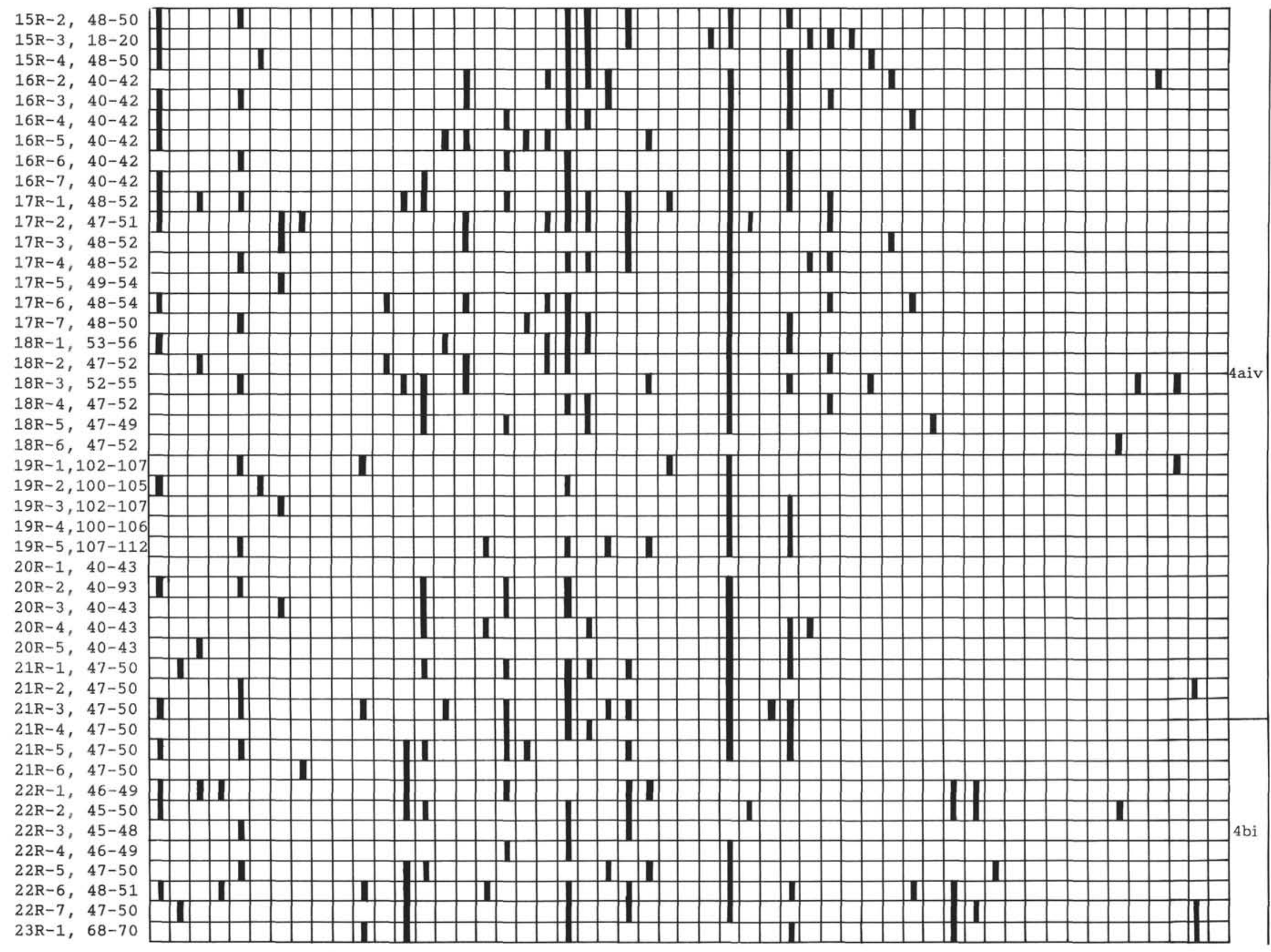




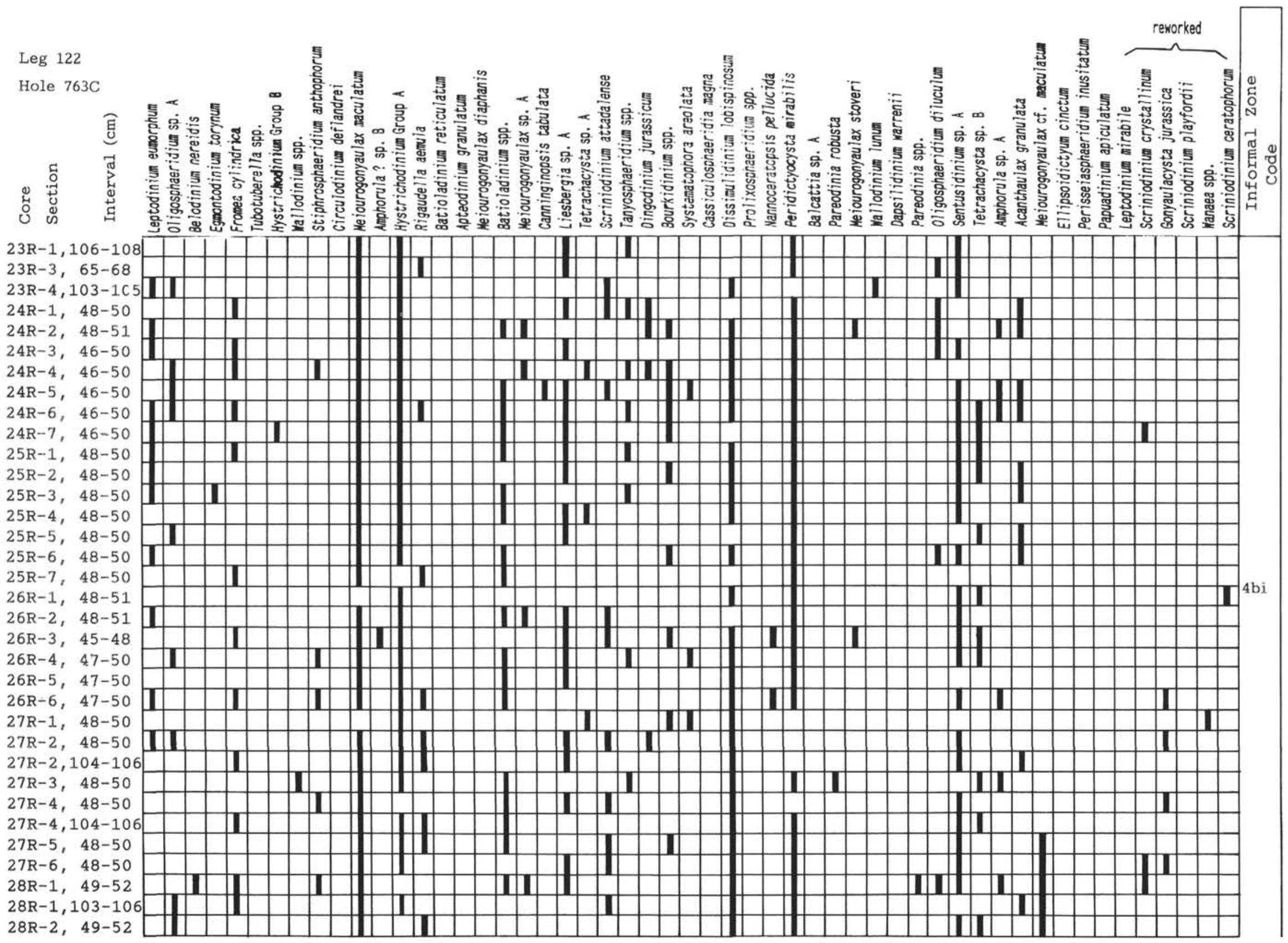

Figure 5 (continued). 


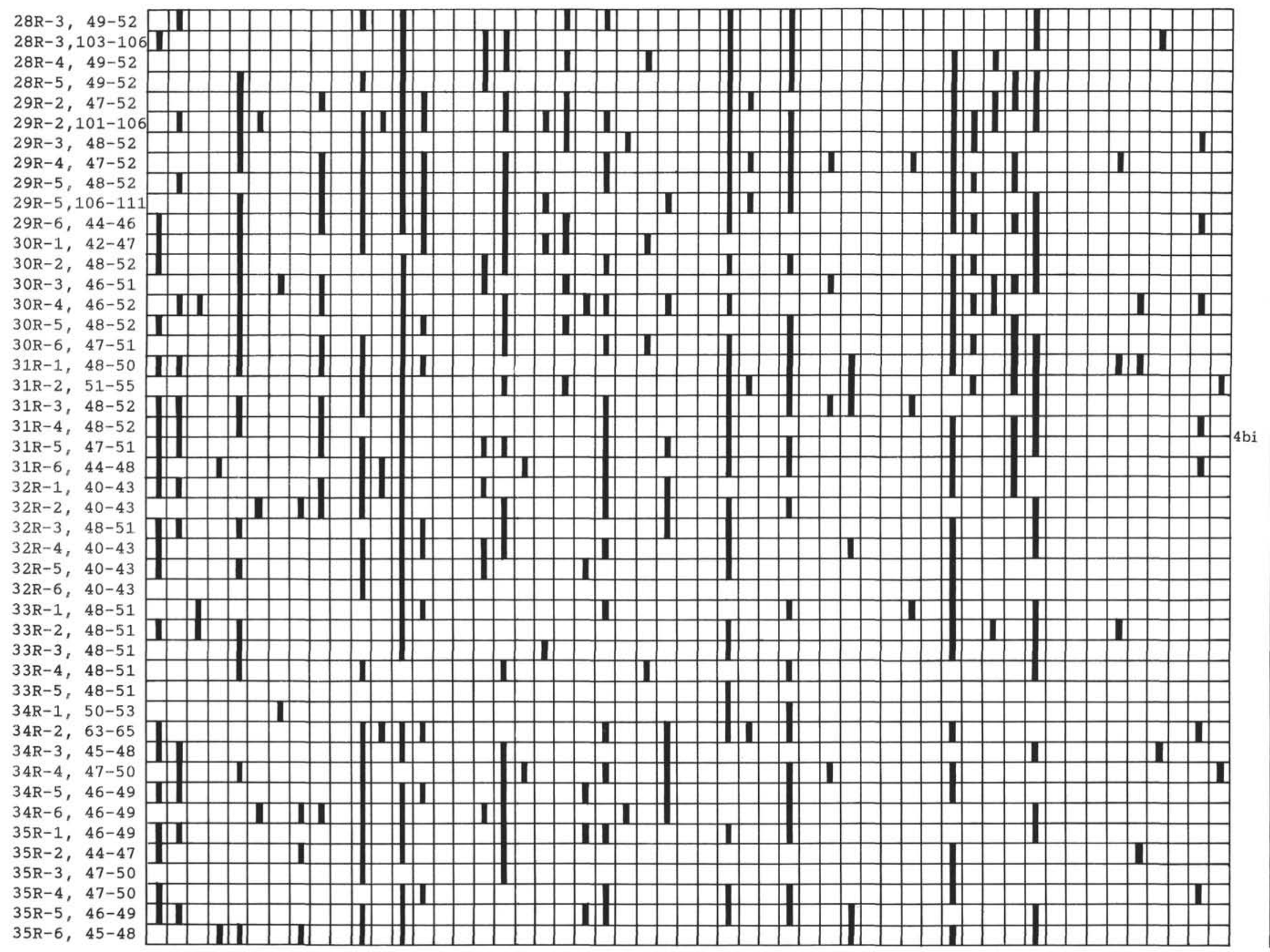




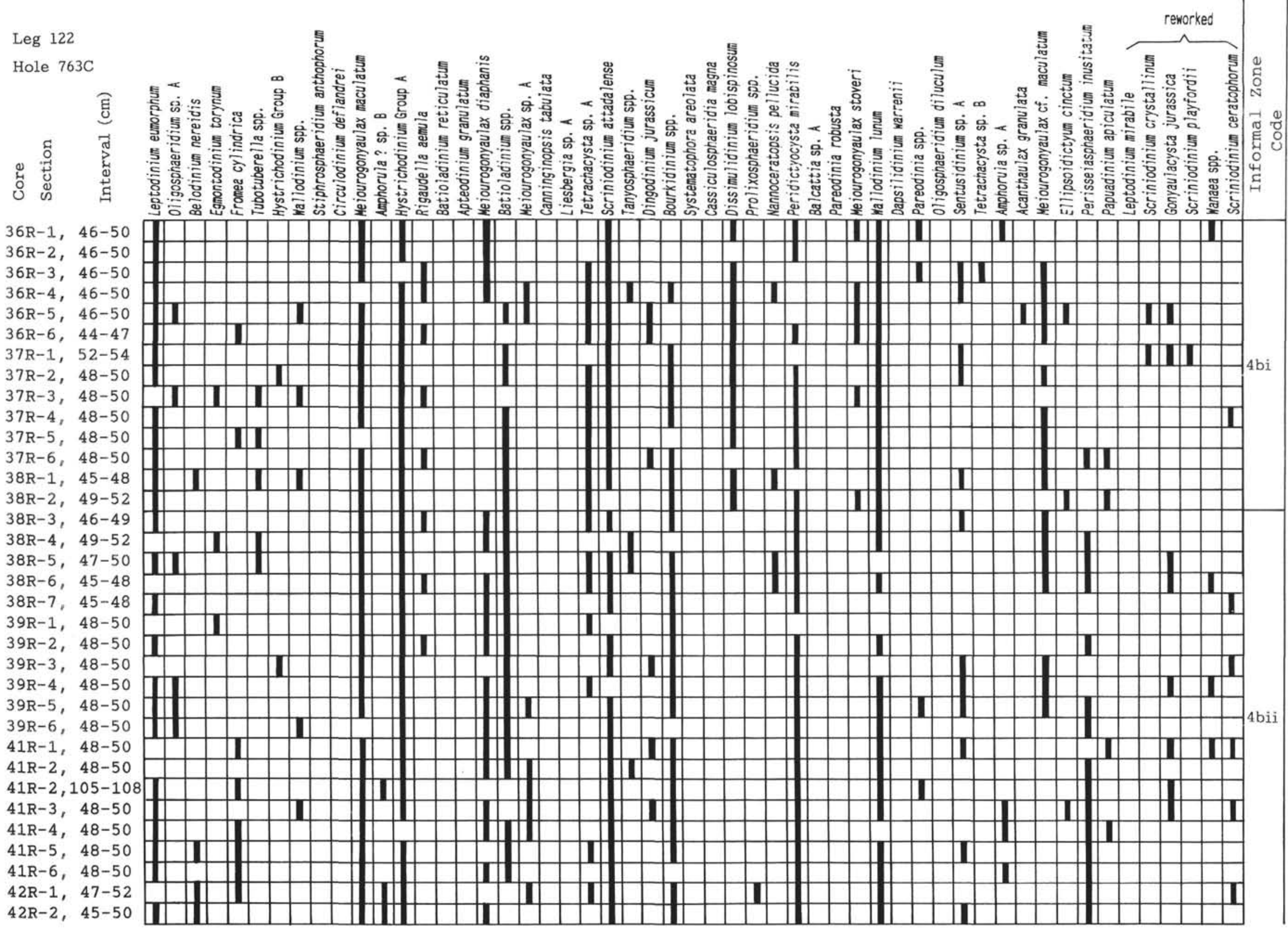

Figure 5 (continued). 


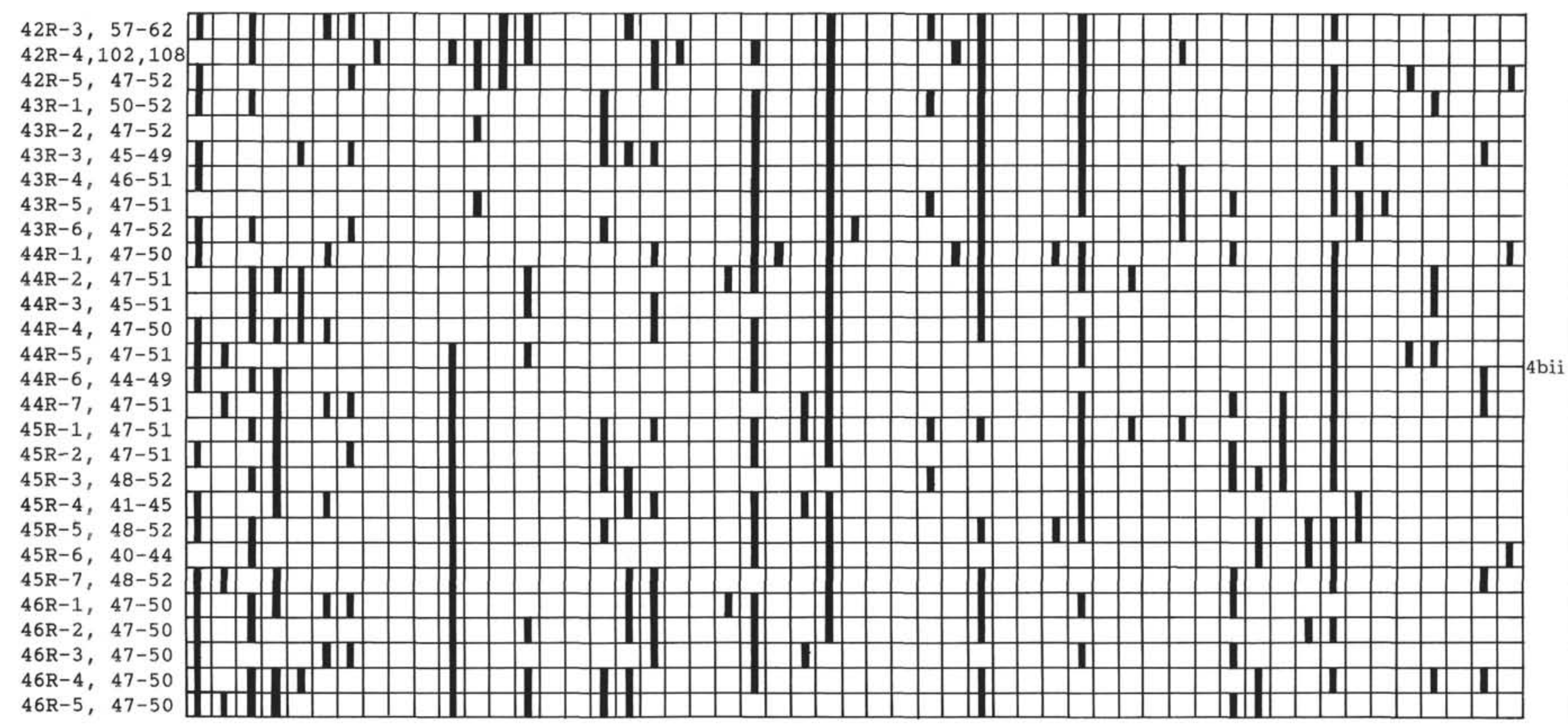

Figure 5 (Continued). 
hole occurrence of Batioladinium reticulatum is in Sample $122-763 \mathrm{C}-21 \mathrm{R}-3,47-50 \mathrm{~cm}$. Based on the range of these dinoflagellate cysts the interval from Samples 122-763B$50 \mathrm{X}-1,48-51 \mathrm{~cm}$, through $122-763 \mathrm{C}-10 \mathrm{R}-2,48-51 \mathrm{~cm}$, can be assigned to the upper Batioladinium reticulatum Zone (4aiii) and the interval from Samples 122-763C-10R-3, 107-109 cm, through $122-763 \mathrm{C}-21 \mathrm{R}-3,47-50 \mathrm{~cm}$, to the lower Batioladinium reticulatum Zone (4aiv).

Dissimulidinium lobispinosum Zone (4bi); Samples 122763C-21R-4, 47-50 cm, through 122-763C-38R-2, 49-52 cm; suggested age: middle to late Berriasian.

Cassiculosphaeridia delicata Zone (4bii); Samples 122763C-38R-3, 46-49 cm, through 122-763C-46R-5, 47-50 cm; suggested age: middle Berriasian.

The nearly continuous presence of Perisseiasphaeridium inusitatum in this interval suggests, that the uppermost part of this zone is missing or condensed.

\section{CONCLUSION AND CORRELATION}

Aptian to Quaternary sediments of the central Exmouth Plateau have yielded very few palynomorphs. The youngest dinoflagellate cysts were recorded from the black shale close to the Turonian/Cenomanian boundary. Samples from the chalk below this unit yielded only meager numbers of dinoflagellate cysts and have not been zoned.

Aptian dinoflagellate cysts are recognized at Site 763 in the interval from Samples 122-763B-39X-1, 47-50 cm, through 122-763B-42X-4, 45-49 cm. Except for very few pollen, no terrestrial palynomorphs, wood fragments, or cuticles were found in and above this interval. Below this interval spores, pollen, and plant debris are sporadically common. Poor preservation and the rare occurrence of dinoflagellate cysts do not allow a clear stratigraphic determination; however, the presence of Odontochitina operculata and the absence of Herendeenia postprojecta, Epitricysta vinckensis, and Belodinium dysculum suggest a possible Aptian sequence down to Sample 122-763B-43X-1, 44-47 cm.

A Barremian sequence is recognized at both sites. At Site 762 it occupies the interval from Samples 122-762C-79X-1, $14-17 \mathrm{~cm}$, through $122-762 \mathrm{C}-79 \mathrm{X}-\mathrm{CC}$, and at Site 763 it occupies the interval from Samples 122-763B-43X-3, 48-50 $\mathrm{cm}$, through 122-763B-46X-5, 45-49 cm. Both intervals contain a dinoflagellate cyst assemblage of the Muderongia australis Zone (2dii to iii), which is suggested to be Barremian in age. A useful biostratigraphic marker within this zone (base of Herendeenia postprojecta) allows the correlation between Site 763 and Vinck-1. The first occurrence of Herendeenia postprojecta can be recognized at Site 763 between 1971 and 1976 meters below sea level (mbsl) and at Vinck-1 at 1976.8 mbsl (Fig. 6). The same event is recognized at Site 762 at 2202 mbsl, and at Eendracht-1 at 2191 mbsl.

The Muderongia testudinaria Zone (2div), which is suggested to be middle to late Hauterivian in age, is also recognized at both sites. In Hole $762 \mathrm{C}$ this zone is represented only by Sample $122-762 \mathrm{C}-80 \mathrm{X}-\mathrm{CC}$, and at Site 763 by the interval from Samples 122-763B-46X-6, 44-48 cm, through 122-763B$47 \mathrm{X}-\mathrm{CC}, 46-49 \mathrm{~cm}$. The basis of the Muderongia testudinaria Zone is defined by the oldest occurrence of Dingodinium cerviculum and is recognized at Site 762 at $2207.9 \mathrm{mbsl}$, at Eendracht-1 at $2193.1 \mathrm{mbsl}$, at Site 763 at $1989.5 \mathrm{mbsl}$, and at Vinck-1 at $1989.1 \mathrm{mbsl}$.

Dinoflagellate cysts with a middle Valanginian to early Hauterivian age could not be found at Site 762; however, they are reported from Eendracht from the interval from 2194.9 to $2199.0 \mathrm{mbsl}$. At Site 763 this age is represented by the interval from Samples 122-763B-48X-1, 108-111 cm, through 122$763 \mathrm{~B}-48 \mathrm{X}-4,50-53 \mathrm{~cm}$. However, the preservation and abun- dance of the dinoflagellate cysts do not allow this interval to be differentiated into separate zones.

The top of the Egmontodinium torynum Zone (4ai-ii), which marks a major extinction event, is recognized at both sites. There is also a palynofacies change at this level. Above this horizon the sediment contains sparse or sporadically common terrestrial palynomorphs, whereas downhole from this level terrestrial palynomorphs dominate most samples. This horizon is recognized in Hole $762 \mathrm{C}$ in Sample 122-763C$81 \mathrm{X}-1,47-50 \mathrm{~cm}$, and at Site 763 in Sample 122-763B-48X-5, $48-52 \mathrm{~cm}$, and is suggested to be uppermost Berriasian to lowermost Valanginian in age. The underlying Sample 122$762 \mathrm{C}-81 \mathrm{X}-1,112-115 \mathrm{~cm}$, at Site 762 and the interval from Samples 122-763B-49X-1, 48-50 cm, through 122-763B$49 \mathrm{X}-4,46-48 \mathrm{~cm}$, contain only a few, poorly preserved dinoflagellate cysts and cannot be clearly assigned to the Egmontodinium torynum dinoflagellate Zone.

In the Berriasian stage three zone boundaries can be recognized at Site 762 , which can be correlated with those from Site 763, Eendracht-1, and Vinck-1. The first boundary (4ai-ii to 4aiii) is marked by the first downhole occurrence of Batioladinium reticulatum and is located at Site 762 in Sample $122-762 \mathrm{C}-81 \mathrm{X}-2,50-54 \mathrm{~cm}(2210.4 \mathrm{mbsl})$, at Site 763 in Sample 122-763B-50X-1, 48-51 cm, at Eendracht-1 at 2201.1 mbsl, and at Vinck-1 at 2022.5 mbsl. The interval between 1989.1 and $2022.5 \mathrm{mbsl}$ at Vinck-1 cannot be zoned due to the absence of adequate samples. Therefore, this interval may include the youngest occurrence of Egmontodinium torynum and the youngest occurrence of Batioladinium reticulatum.

The second boundary (4aiii to 4aiv) is marked by the first downhole occurrence of Dissimulidinium lobispinosum and is located at Site 762 in Sample 122-762C-86X-1, 112-115 cm (2243.5 mbsl), at Site 763 in Sample 122-763C-10R-3, 107-109 $\mathrm{cm}$ (2056.7 mbsl), at Eendracht-1 at $2235 \mathrm{mbsl}$, and at Vinck-1 at $2074.3 \mathrm{mbsl}$.

The third correlatable boundary (4aiv to $4 \mathrm{bi}$ ) is marked by the last downhole occurrence of Batioladinium reticulatum and is located at Site 762 in Sample 122-762C-86X-4, 18-20 $\mathrm{cm}$ (2247.1 mbsl), at Site 763 in Sample 122-763C-21R-3, $47-50 \mathrm{~cm}$ (2160.6 mbsl), at Eendracht-1 at $2236.5 \mathrm{mbsl}$, and at Vinck-1 at 2041.5 mbsl. The difference of the last downhole occurrence of Batioladinium reticulatum at Site 763 and at Vinck-1 (here above the youngest occurrence of Dissimulidinium lobispinosum) may be an effect of ecological overprinting.

A further correlatable boundary is marked by the oldest occurrence of Dissimulidinium lobispinosum. This event is not recorded at Site 762 because the bottom of Hole $762 \mathrm{C}$ lies above this level within the Dissimulidinium lobispinosum Zone (4bi). At Eendracht-1 it is reported at $2299.0 \mathrm{mbsl}$, at Site 763 in Sample 122-763C-38R-2, 49-52 cm (2320.6 mbsl), and at Vinck-1 at 2365.0 mbsl. The bottom of Hole 763 lies within the Cassiculosphaeridia delicata dinoflagellate Zone (4bii), which is suggested to be middle Berriasian in age.

\section{TAXONOMY}

\section{Index of Species}

Acanthaulax granulata (Klement, 1960) Brenner, 1988

Amphorula? sp. A

Amphorula? sp. B

Apteodinium granulatum Eisenack, 1958

Ascodinium parvum (Cookson and Eisenack, 1958) Cookson and Eisenack, 1960a

Atlantodinium? sp. A

Balcattia sp. A of Helby et al., 1987

Batiacasphaera subtilis Stover and Helby, 1987a

Batioladinium micropodum Eisenack and Cookson, 1960 


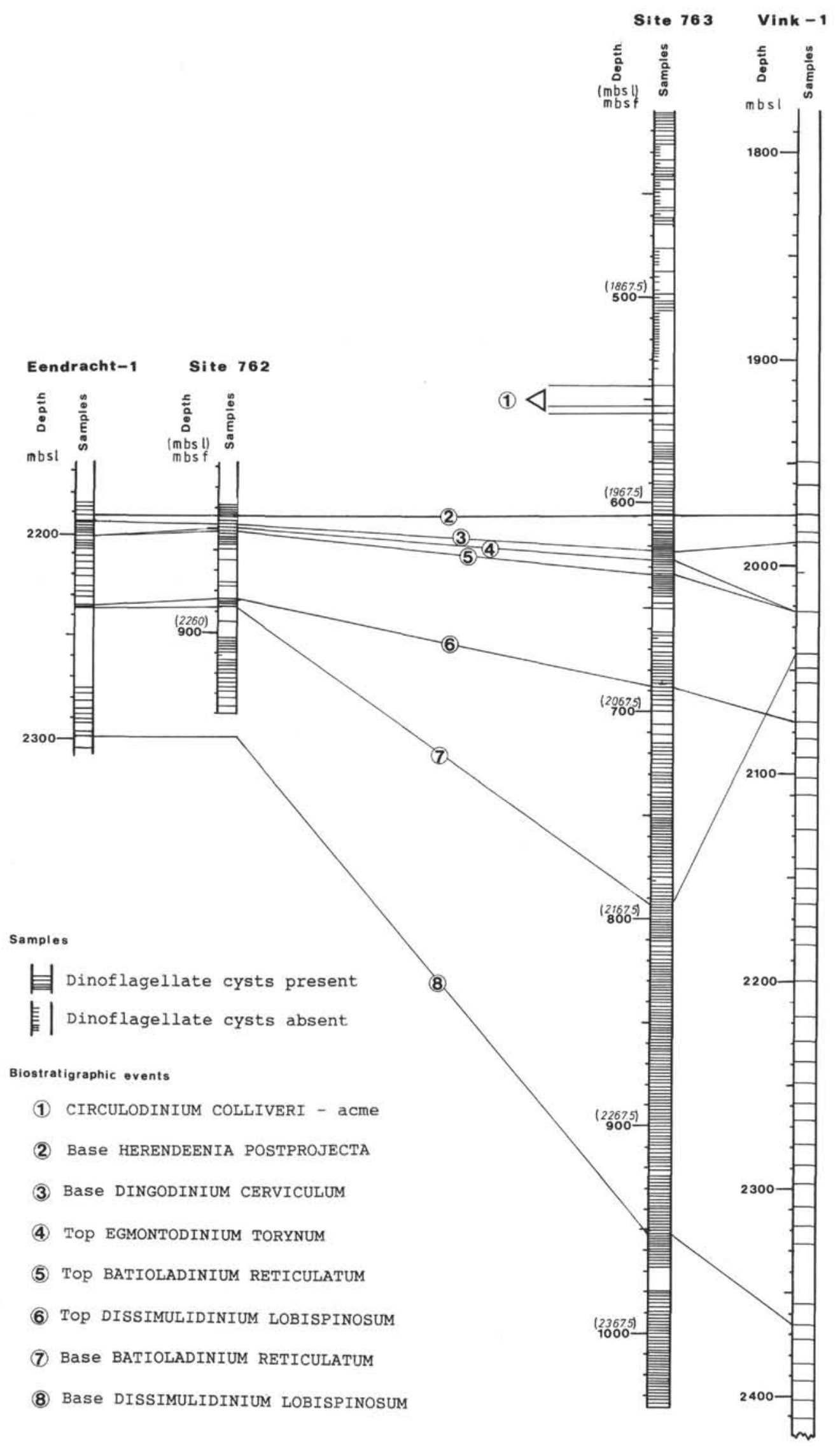

Figure 6. Correlation on basis of biostratigraphic events between Sites 762, 763, Eendracht-1, and Vinck-1. 
Batioladinium reticulatum Stover and Helby, 1987a

Belodinium dysculum Cookson and Eisenack, 1960b

Belodinium nereidis Stevens and Helby, 1987

Canninginopsis tabulata (Davey and Verdier, 1974) Duxbury, 1977

Carpodinium granulatum Cookson and Eisenack, 1962

Cassiculosphaeridia magna Davey, 1974

Cassiculosphaeridia delicata Stover and Helby, 1987a

Circulodinium colliveri (Cookson and Eisenack, 1960b) Helby, 1987

Circulodinium deflandrei (Alberti, 1961) Helby, 1987

Cymososphaeridium validum Davey, 1982

Dapcodinium priscum Evitt, 1961

Dapsilidinium warrenii (Habib, 1975) Lentin and Williams, 1981

Diconodinium davidii Morgan, 1975

Dingodinium cerviculum Cookson and Eisenack, 1958

Dingodinium jurassicum Cookson and Eisenack, 1958

Dissimulidinium lobispinosum May et al., 1987

Egmontodinium torynum (Cookson and Eisenack, 1960b) Davey, 1979

Ellipsoidictyum cinctum Klement, 1960

Epitricysta vinckensis Stover and Helby, 1987a

Exochosphaeridium arnace Davey and Verdier, 1974

Fromea cylindrica (Cookson and Eisenack, 1960b) Stover and Evitt, 1978

Gonyaulacysta helicoidea (Eisenack and Cookson, 1960) Sarjeant, 1966

Gonyaulacysta jurassica (Deflandre, 1938b) Norris and Sarjeant, 1965

Herendeenia postprojecta Stover and Helby, 1987a

Hystrichodinium Group A

Hystrichodinium Group B

Kaiwaradinium scrutillinum Backhouse, 1987

Kalyptea wisemaniae Stover and Helby, 1987a

Leptodinium eumorphum (Cookson and Eisenack, 1960b) Sarjeant, 1969

Leptodinium mirabile Klement, 1960

Liesbergia sp. A

Meiourogonyaulax diaphanis Stevens, 1987

Meiourogonyaulax maculata Backhouse, 1988

Meiourogonyaulax $\mathrm{cf}$. maculata Backhouse, 1988

Meiourogonyaulax stoveri Millioud, 1969

Meiourogonyaulax sp. A

Muderongia australis Helby, 1987

Muderongia macwhaei Cookson and Eisenack, 1958

Muderongia testudinaria Burger, 1980

Muderongia tetracantha (Gocht, 1957) Alberti, 1961

Nannoceratopsis pellucida Deflandre, 1938a

Odontochitina operculata (Wetzel, 1933) Deflandre and Cookson, 1955

Oligosphaeridium complex (White, 1842) Davey and Williams, 1966

Oligosphaeridium diluculum Davey, 1982

Oligosphaeridium sp. A

Omatia montgomeryi Cookson and Eisenack, 1958

Ovoidinium cinctum (Cookson and Eisenack, 1958) Davey, 1970

Papuadinium apiculatum (Cookson and Eisenack, 1960b) Davey, 1988

Peridictyocysta mirabilis (Cookson and Eisenack, 1958) Cookson and Eisenack, 1974

Perisseiasphaeridium inusitatum Stevens and Helby, 1987

Phoberocysta neocomica (Gocht, 1957) Millioud, 1969

Phoberocysta burgeri Helby, 1987

Prolixosphaeridium inequiornatum Stover and Helby, 1987c

Prolixosphaeridium parvispinum (Deflandre, 1937) Davey et al., 1969

Pseudoceratium iehiense Helby and May in Helby, 1987

Pseudoceratium turneri Cookson and Eisenack 1958

Rigaudella aemula (Deflandre, 1938b) Below, 1982

Scriniodinium attadalense (Cookson and Eisenack, 1958) Eisenack, 1967

Scriniodinium ceratophorum Cookson and Eisenack, 1960b

Scriniodinium crystallinum (Deflandre, 1938b) Klement, 1960

Scriniodinium playfordii Cookson and Eisenack, 1960b

Senoniasphaera tabulata Backhouse and Helby in Helby 1987

Sentusidinium sp. A

Spiniferites ramosus (Ehrenberg, 1838)) Loeblich and Loeblich, 1966

Stiphrosphaeridium anthophorum (Cookson and Eisenack, 1958) Davey, 1982
Systematophora areolata Klement, 1960

Tetrachacysta sp. A

Tetrachacysta sp. B

Tubotuberella vlamingii Backhouse, 1987

Wallodinium lunum (Cookson and Eisenack, 1960a) Lentin and Williams, 1973

Yalkalpodinium scutum Morgan, 1980

\section{Remarks On Selected Dinoflagellate Cysts \\ Amphorula? sp. A \\ (PI. 2, Figs. 3 and 6)}

Remarks. This form differs from Amphorula in lacking paracingular processes. Therefore, it is questionably included in Amphorula.

Description. The distinctive, relatively thick cyst wall is approximately $1.5-2 \mu \mathrm{m}$ thick. The paratabulation is gonyaulacoid with a "Acanthaulax-type" dorsal tabulation line-up (Brenner, 1988), indicated by high, thin, arcuate penitabular septa that are incomplete along the paracingulum. The septa of the apical paraplates open toward the apex and the septa of the antapical paraplate is complete and circular to rectangular.

Dimensions. Cyst diameter $75-90 \mu \mathrm{m}$; septa $10-15 \mu \mathrm{m}$.

Comparison. Amphorula? sp. A differs from Amphorula delicata van Helden (1986) and from Amphorula metaelliptica Dodekova (1969) in having no perforated septa, and from Amphorula dodekovae Zotto et al. (1987) in having incomplete and higher penitabular septa at the precingular and postcingular paraplates.

Amphorula? sp. B

(Pl. 2, Figs. 1, 2, 4, and 5)

Remarks. This form has at the pre- and postcingular paraplates penitabular to intratabular horseshoe-shaped septa, open toward the cingulum and at the apical paraplates toward the apex. The septa are perforated and could be reduced to a connected process group. The septa of the antapical and the posterior intercalar paraplate are complete and circular with a tubiform to trumpet-like shape. The cingular and sulcal processes are solid.

Dimensions. Cyst without processes/septa $50-65 \mu \mathrm{m}$; processes $10-22 \mu \mathrm{m}$.

$$
\text { Atlantodinium? sp. A }
$$$$
\text { (PI. 2, Figs. } 7 \text { and } 8 \text { ) }
$$

Remarks. This form differs from Atlantodinium and from Alisocysta Stover and Evitt (1978) in lacking penitabular paracingular ridges or septa and from Egmontodinium Gitmez and Sarjeant (1972), and from Histiophora Klement (1960) in having penitabular pre-, post-, and antapical septa. The height of the septa varies from less than $2 \mu \mathrm{m}$ up to $18 \mu \mathrm{m}$ and they are reduced in the cingular area. This indicates a similar reducing process as observed with the Egmontodinium-Histiophora group (Brenner, 1988).

Dimensions. Cyst diameter 60-75 $\mu \mathrm{m}$.

$$
\text { Balcattia sp. A of Helby et al., } 1987
$$$$
\text { (Pl. 1, Figs. } 2 \text { and 3) }
$$

Remarks. This form differs from the spherical to subspherical Balcattia cirrifera Cookson and Eisenack (1974) in having a long, elliptical cyst, and from Arachnodinium antarcticum Wilson and Clowes (1982) and Flamingoia cometa Stevens and Helby (1987) in having no antapical branch.

Dimensions. Cyst length (without operculum) 45-55 $\mu \mathrm{m}$, cyst width $30-35 \mu \mathrm{m}$, antapical processes $30-35 \mu \mathrm{m}$.

\section{Hystrichodinium Group A}

Remarks. This group included different species of the Hystrichodinium type with less than 25 processes. The following described species could be found in the material of Site 762 and 763: Hystrichodinium amphiacanthum Cookson and Eisenack (1958), Hystrichodinium oligacanthum Deflandre and Cookson, 1955, and Hystrichodinium voigtii (Alberti, 1961) Davey (1974).

\section{Hystrichodinium Group B}

Remarks. This group includes different species of the Hystrichodinium type with more than 25 processes. The following described species could be found in the material of Site 762 and 763: Hystrichodinium compactum Alberti (1961), Hystrichodinium isodiametri- 
cum (Cookson and Eisenack, 1958) Stover and Evitt (1978), and Hystrichodinium pulchrum Deflandre, 1935.

$$
\text { Liesbergia sp. A }
$$

(PI. 1 Figs. 1 and 5)

Description. Gonyaulacoid cyst with "Acanthaulax-type" dorsal tabulation line-up and precingular archeopyle $\left(\mathrm{P}_{3^{\prime \prime}}\right)$. The ornamentation consists of low spines $(2-5 \mu \mathrm{m})$ forming spine rows with distal trabecula at the parasutural ridges. The apical horn is formed by anastomosing fibers.

Dimensions. Cyst diameter 45-60 $\mu \mathrm{m}$; horn length 8-14 $\mu \mathrm{m}$. Meiourogonyaulax cf. maculata Backhouse, 1988 (PI. 1, Figs. 7 and 12)

Remarks. Meiourogonyaulax cf. maculata differs from Meiourogonyaulax maculata in having initial zone paraporoids (Gocht, 1987) at the pre- and postcingular paraplates. The antapical paraplate often shows a spongy wall structure that could also appear in the accession zone (Gocht, 1987) of the pre- and postcingular paraplates.

Dimensions. Cyst diameter 65-80 $\mu \mathrm{m}$.

\section{Meiourogonyaulax sp. A}

(Pl, 2, Fig. 9)

Remarks. This form is similar to Meiourogonyaulax sp. B figured by Helby et al. (1987).

Dimensions. Cyst diameter 75-90 $\mu \mathrm{m}$.

$$
\begin{aligned}
& \text { Oligosphaeridium sp. A } \\
& \text { (Pl, 1, Figs. } 4 \text { and } 8 \text { ) }
\end{aligned}
$$

Remarks. This form is close to Oligosphaeridium complex but differs in having foveolate processes and a granulate to verrucate periphragm.

Dimensions. Cyst diameter without processes $40-50 \mu \mathrm{m}$; processes $20-40 \mu \mathrm{m}$.

Ovoidinium cinctum (Cookson and Eisenack, 1958) Davey, 1970

Remarks. Helenes (1983) considered on the basis of paratabulation and wall structures that Ovoidinium is a junior synonym of Ascodinium. However, Ovoidinium has a compound apical-intercalary archeopyle of the type $\left(4 \mathrm{~A}_{1-4}, 3 \mathrm{I}_{1-3 \mathrm{a}}\right) \mathrm{a}$, whereas Ascodinium has a compound apical-intercalary archeopyle of the type $\left(\mathrm{A}_{3} \mathrm{I}_{2 \mathrm{a}}\right) \mathrm{a}$. Based on its distinctive archeopyle, Ovoidinium is to regard as a separate genus (Bujak and Davies, 1983).

\section{Sentusidinium sp. A \\ (Pl. 1, Figs. 10 and 11)}

Remarks. This form differs from all other described species of Sentusidinium in having thin, solid, and capitate processes.

Dimensions. Cyst diameter 50-65 $\mu \mathrm{m}$; processes 5-10 $\mu \mathrm{m}$.

\section{Tetrachacysta sp. A}

(PI. 1, Fig. 9)

Remarks. This form differs from Tetrachacysta allenii Backhouse (1988) in bearing small, simple spines (1-2 $\mu \mathrm{m})$.

Dimensions. Cyst diameter 40-50 $\mu \mathrm{m}$.

\section{Tetrachacysta sp. B}

(PI. 1, Fig. 13)

Remarks. This form differs from Tetrachacysta allenii Backhouse (1988) and Tetrachacysta sp. A in bearing long, bifurcate processes and from Dissimulidinium lobispinosum in being quadrilobate rather than trilobate.

Dimensions. Cyst diameter without processes $45-60 \mu \mathrm{m}$; processes 5-20 $\mu \mathrm{m}$, usually around $10 \mu \mathrm{m}$.

\section{ACKNOWLEDGMENTS}

Thanks are due to the Deutsche Forschungsgemeinschaft, Bonn, for supporting the present study, to H. P. Luterbacher, who made it possible to begin this study at the Institut für Geologie und Paläontologie Tübingen, and to J. Thiede, who facilitated the continuation of this study at GEOMAR, Kiel. I also thank R. Helby (Lane Cove, Australia) for helpful discussion on taxonomy and biostratigraphy, R. Boyd (GEOMAR) for stratigraphical and sedimentological discussion, Dr. G. Dürr (Institut für Geologie und Paläontologie,
Tübingen) for processing a part of the samples, and D. Habib for reviewing this paper.

\section{REFERENCES}

Alberti, G., 1961. Zur Kenntnis mesozoischer und alttertiärer Dinoflagellaten und Hystrichosphaerideen von Nord-und Mitteldeutschland sowie einigen anderen europäischen Gebieten. Palaeontographica $B, 116: 1-58$.

Backhouse, J., 1987. Microplankton zonation of the Lower Cretaceous Warnbro Group, Perth Basin, Western Australia. In Jell, P. A. (Ed.), Studies in Australian Mesozoic Palynology. Mem. Assoc. Australas. Palaeontol., 4:205-226.

1988. Late Jurassic and Early Cretaceous Palynology of the Perth Basin, Western Australia. Bull. Geol. Surv. West. Aust., 135:1-233.

Below, R., 1982. Rigaudella, ein neues Genus von DinoflagellatenZysten. Neues Jahrb. Geol. Palaeontol. Monatsh., 137-150.

Brenner, W., 1988. Dinoflagellaten aus dem Unteren Malm (Oberer Jura von Süddeutschland; Morphologie, ökologie, Stratigraphie. Tubinger Mikropalaont. Mitt., 6:1-115.

Bujak, J. P., and Davies, E. H., 1983. Modern and fossil Peridiniineae. Contrib. Ser. Am. Assoc. Stratigr. Palynol., 13:1-203.

Burger, D., 1980. Palynology of the Lower Cretaceous of the Surat Basin. Bull. Bur. Miner. Resour. Geol. Geophys. Aust., 189:1-106.

Cookson, I. C., and Eisenack, A., 1958. Microplankton from Australian and New Guinea upper Mesozoic sediments. Proc. $R$. Soc. Victoria, 70:19-79.

1960a. Microplankton from Australian Cretaceous sediments. Micropaleontology, 6:1-18.

1960b. Upper Mesozoic microplankton from Australia and New Guinea. Palaeontology, 2:243-261.

, 1962. Additional microplankton from Australian Cretaceous sediments. Micropaleontology, 8:485-507.

1974. Microplankton aus australischen mesozoischen und Tertiären Sedimenten. Palaeontographica B, 148:44-93.

Davey, R. J., 1970. Non-calcareous microplankton from the Cenomanian of England, northern France and North America, Part 2. Bull. Br. Mus. Nat. Hist. (Geol.), 18:333-397.

1974. Dinoflagellate cysts from the Barremian of the Speeton Clay, England. Birbal Sahni Inst. Palaeobot. Spec. Publ., 3:41-75

, 1979. The stratigraphic distribution of dinocysts in the Portlandian (latest Jurassic) to Barremian (Early Cretaceous) of northwest Europe. Contrib. Ser. Am. Assoc. Stratigr. Palynol., $5 \mathrm{~B}: 48-81$.

1982. Dinocyst stratigraphy of the latest Jurassic to Early Cretaceous of the Haldager No.1 borehole. Geol. Surv. Denmark Ser. B, 6:1-57.

1988. Palynological zonation of the Lower Cretaceous, Upper and uppermost Middle Jurassic in the Northwestern Papuan Basin of Papua, New Guinea. Mem. Geol. Surv. Papua New Guinea, 13:1-77.

Davey, R. J., Downie, C., Sarjeant, W.A.S., and Williams, G. L., 1969. Generic reallocations. In Davey, R. J., Downie, C., Sarjeant, W.A.S., and Williams, G. L. (Eds.), Appendix to Studies on Mesozoic and Cainozoic Dinoflagellate Cysts. Bull. Br. Mus. Nat. Hist. (Geol.), Append. Suppl., 3:15-17.

Davey, R. J., and Verdier, J. P., 1974. Dinoflagellate cysts from the Aptian type sections at Gargas and La Bédoule, France. Palaeontology, 17:623-654

Davey, R. J., and Williams, G. L., 1966. The genus Hystrichosphaeridium and its allies. In Davey, R. J., Downie, C., Sarjeant, W.A.S., and Williams, G. L. (Eds.), Studies on Mesozoic and Cainozoic Dinoflagellate Cysts. Bull. Br. Mus. Nat. Hist. (Geol.), Suppl., 3:28-52.

Deflandre, G., 1935. Considération biologiques sur les microorganismes d'origine planctonique conservés dans les silex de la craie. Bull. Biol. Fr. Belg., 69:213-244.

1937. Microfossiles des silex crétacés. Deuxième partie. Flagellés incertae sedis Hystrichosphaeridés. Sarcodinés. Organismes divers. Ann. Paleontol., 26:51-103.

, 1938a. Sur le microplancton des mers jurassiques, conservé à l'état de matière organique dans les marnes de Villers-sur-Mer. C. R. Acad. Sci. Paris, 206:687-689. 
1938b. Microplancton des mers jurassiques, conservé dans les marnes de Villers-sur-Mer (Calvados). Etude liminaire et considérations générales. Trav. Stn. Zool. Wimereux, 13:147-200.

Deflandre, G., and Cookson, I. C., 1955. Fossil microplankton from Australian late Mesozoic and Tertiary sediments. Aust. J. Mar. Freshwater Res., 6:242-313.

Dodekova, L., 1969. Dinoflagellés et acritarches du Tithonique aux environs de Pleven, Bulgarie Central du Nord. Bull. Geol. Inst. Ser. Paleontol. (Sofia), 18:13-24.

Duxbury, S., 1977. A palynostratigraphy of the Berriasian to Barremian of the Speeton Clay of Speeton, England. Palaeontographica $B, 160: 17-67$.

Ehrenberg, C. G., 1838. über das Massenverhältnis der jetzt lebenden Kiesel-Infusorien und über ein neues Infusorien-Conglomerat als Polierschiefer von Jastraba in Ungarn. Abh. K. Preuss. Akad. Wiss., 1836:109-135.

Eisenack, A., 1958. Mikroplankton aus dem norddeutschen Apt. Neues Jahrb. Geol. Palaeontol. Abh., 106:383-422.

1967. Katalog der Fossilen Dinoflagellaten, Hystrichos phaeren und Verwandten Mikrofossilien. Band I. Dinoflagellaten. 1. Ergänzungslieferung, Stuttgart (E. Schweizerbart'sche Verlagsbuchhandlung).

Eisenack, A., and Cookson, I. C., 1960. Microplankton from Australian Lower Cretaceous sediments. Proc. R. Soc. Victoria, 72:1-11.

Evitt, W. R., 1961. Dapcodinium priscum n. gen., n. sp., a dinoflagellate from the Lower Lias of Denmark. J. Paleontol., 35:996-1002.

Gitmez, G. U., and Sarjeant, W.A.S., 1972. Dinoflagellate cysts and acritarchs from the Kimmeridgian (Upper Jurassic) of England, Scotland and France. Bull. Br. Mus. Nat. Hist. (Geol.), 21:171257.

Gocht, H., 1957. Mikroplankton aus dem nordwestdeutschen Neokom (Teil I). Palaeontol. Z., 31:163-185.

1987. Morphogenetische Deutung und Bezeichnung ausgewählter Merkmale bei Dinoflagellaten-Zysten. Neues Jahrb. Geol. Palaeontol. Monatsh., 12:705-725

Habib, D., 1975. Neocomian dinoflagellate zonation in the western North Atlantic. Micropaleontology, 21:373-392.

Haq, B. U., von Rad, U., O'Connell, S., et al., 1990. Proc. ODP, Init. Repts., 122: College Station, TX (Ocean Drilling Program).

Heilmann-Clausen, C., 1987. Lower Cretaceous dinoflagellate biostratigraphy in the Danish Central Trough. Danm. Geol. Unders. Ser. A, 17:1-89.

Helby, R., 1987. Muderongia and related dinoflagellates of the latest Jurassic to Early Cretaceous of Australia. In Jell, P. A. (Ed.), Studies in Australian Mesozoic Palynology. Mem. Assoc. Australas. Palaeontol., 4:297-336.

Helby, R., Morgan, R., and Partridge, A. D., 1987. A palynological zonation of the Australian Mesozoic. In Jell, P. A. (Ed.), Studies in Australian Mesozoic Palynology. Mem. Assoc. Australas. Palaeontol., 4:1-94.

Helenes, J., 1983. Evaluation of Jurassic-Cretaceous dinoflagellates Ascodinium-Ovoidinium complex. Micropaleontology, 29:255266.

Ingram, B., and Morgan, R., 1988. The development and status of Mesozoic palynostratigraphy of the North West Shelf, Australia. In Purcell, P. G., and Purcell, R. R. (Eds.), The North West Shelf, Australia. Proc. Pet. Expl. Soc. Aust. Symp., 581-590.

Klement, K. W., 1960. Dinoflagellaten und Hystrichosphaerideen aus dem unteren und mittleren Malm Südwestdeutschlands. Palaeontographica $A, 114: 1-104$.

Lentin, J. K., and Williams, G. L., 1973. Fossil dinoflagellates: index to genera and species. Supplement 1. Pap.-Geol. Surv. Can., 73-42:1-176.

1981. Fossil dinoflagellates: index to genera and species, 1981 edition. Geol. Surv. Can. Rep. Ser., B-R-81-12:1-345.

Loeblich, A. R., and Loeblich, A. R., III, 1966. Index to genera, subgenera, and sections of the Pyrrhophyta. Stud. Trop. Oceanogr., 3:1-94.

May, F. E., Stevens, J., and Partridge, A. D., 1987. The Early Cretaceous dinoflagellate, Dissimulidinium lobispinosum gen. et sp. nov. from Western Australia. In Jell, P.A. (Ed.), Studies in Australian Mesozoic Palynology. Mem. Assoc. Australas. Palaeontol., 4:199-204.

Millioud, M. E., 1969. Dinoflagellates and acritarchs from some western European Lower Cretaceous type localities. In Bronniman, P., and Renz, H. H. (Eds.), Proc. First Int. Conf. Planktonic Microfossils, Geneva, 1967, 2:420-434.

Morgan, R., 1975. Some Early Cretaceous organic-walled microplankton from the Great Australian Basin, Australia. J. Proc. R. Soc. N.S.W., 108:157-167.

1980. Palynostratigraphy of the Australian Early and Middle Cretaceous. Mem. Geol. Surv. N.S.W. Palaeontol., 18:1-153.

Norris, G., and Sarjeant, W.A.S., 1965. A descriptive index of genera of fossil Dinophyceae and Acritarcha. N. Z. Geol. Surv. Paleontol. Bull., 40:1-72.

Rawson, P. F., and Riley, L. A., 1982. Latest Jurassic-Early Cretaceous Events and the "Late Cimmerian Unconformity" in the North Sea area. AAPG Bull., 66:2628-2648.

Sarjeant, W.A.S., 1966. Dinoflagellate cysts with Gonyaulax-type tabulation. In Davey, R. J, Downie, C., Sarjeant, W.A.S., and Williams, G. L. (Eds.), Studies on Mesozoic and Cainozoic dinoflagellate cysts. Bull. Br. Mus. Nat. Hist. (Geol.), Suppl. 3:107-156.

1969. Taxonomic changes. In Davey, R. J., Downie, C., Sarjeant, W.A.S., and Williams, G. L. (Eds.), Appendix to "Studies on Mesozoic and Cainozoic dinoflagellate cysts." Bull. Brit. Mus. Nat. Hist. (Geol.), Append. Suppl., 3:7-15.

Stevens, J., 1987. Some Early Cretaceous dinoflagellates from the Cassiculosphaeridia delicata Zone of the Exmouth Plateau, Western Australia. In Jell, P. A. (Ed.), Studies in Australian Mesozoic Palynology. Mem. Assoc. Australas. Palaeontol., 4:185-197.

Stevens, J., and Helby, R., 1987. Some Early Cretaceous dinoflagellates encountered in the Australian Kalyptea wisemaniae Zone. In Jell, P. A. (Ed.), Studies in Australian Mesozoic Palynology. Mem. Assoc. Australas. Palaeontol., 4:165-184.

Stover, L. E., and Evitt, W. R., 1978. Analyses of pre-Pleistocene organic-walled dinoflagellates. Stanford Univ. Publ. Geol. Sci., $15: 1-300$.

Stover, L. E., and Helby, R., 1987a. Early Cretaceous dinoflagellates from the Vinck-1 well, offshore Western Australia. In Jell, P. A. (Ed.), Studies in Australian Mesozoic Palynology. Mem. Assoc. Australas. Palaeontol., 4:227-260.

1987b. Some Australian Mesozoic microplankton index species. In Jell, P. A. (Ed.), Studies in Australian Mesozoic Palynology. Mem. Assoc. Australas. Palaeontol., 4:101-134.

Van Helden, B.G.T., 1986. Dinoflagellate cysts at the JurassicCretaceous boundary, offshore Newfoundland. Can. Palynology, 10:181-199.

Wetzel, O., 1933. Die in organischer Substanz erhaltenen Mikrofossilien des baltischen Kreide-Feuersteins mit einem sedimentpetrographischen und stratigraphischen Anhang. Palaeontographica $A, 77: 141-188$.

White, H. H., 1842. On fossil Xanthidia. Microscopical J., London, 11:35-40.

Wilson, G. J., and Clowes, C. D., 1982. Arachnodinium, a new dinoflagellate genus from the Lower Tertiary of Antarctica. $\mathrm{Pa}$ lynology, 6:97-103.

Woollam, R., and Riding, J. B., 1983. Dinoflagellate cyst zonation of the English Jurassic. Rep. Inst. Geol. Sci., 83:1-41.

Zotto, M., Drugg, W. S., and Habib, D., 1987. Kimmeridgian dinoflagellate stratigraphy in the Southwestern North Atlantic. Micropaleontology, 33:193-213.

Date of initial receipt: 4 June 1990

Date of acceptance: 4 March 1991

Ms 122B-158 

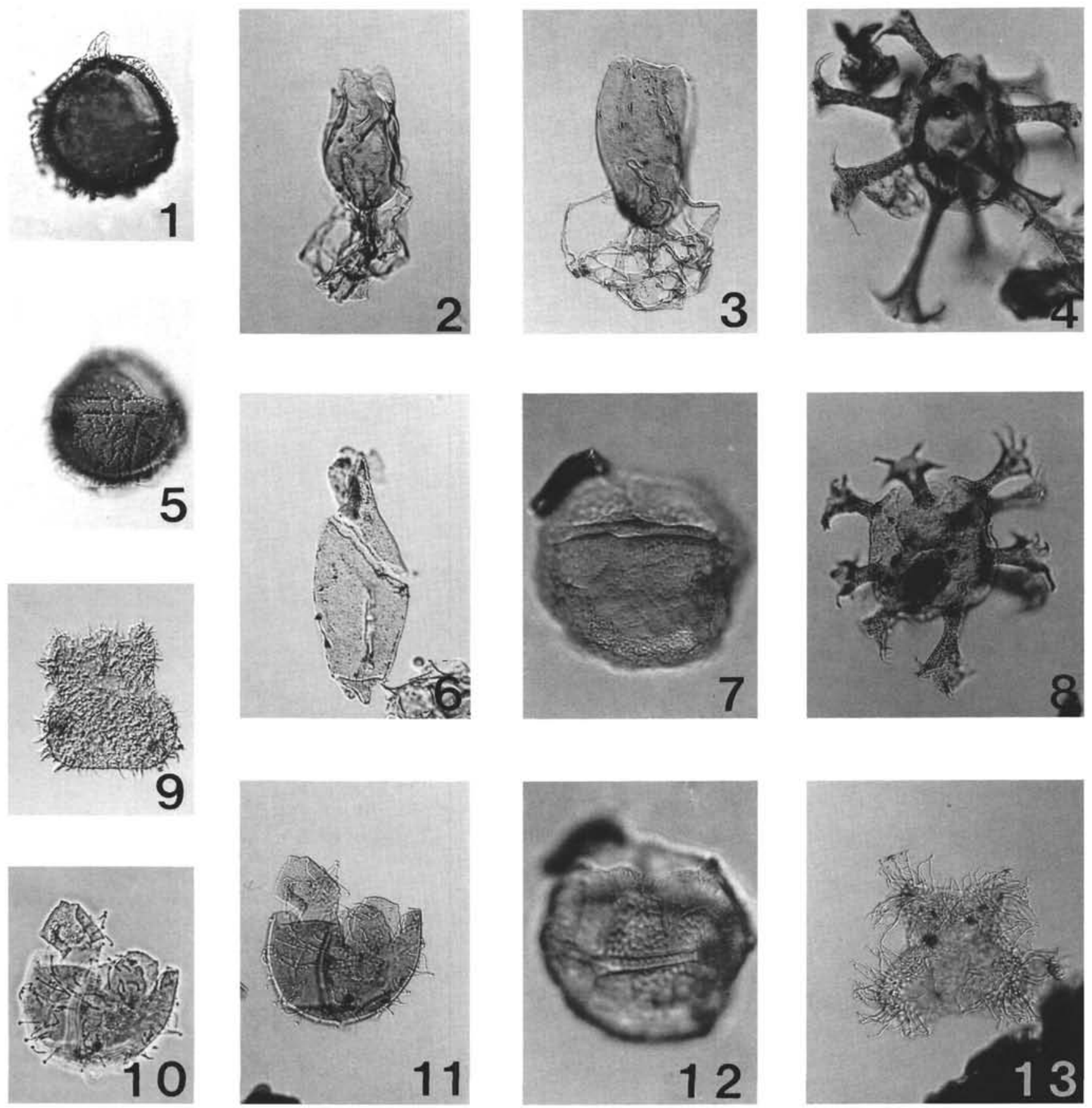

Plate 1. Magnification $\times 500$. 1, 5. Liesbergia $\mathrm{sp}$. A, Sample $122-762 \mathrm{C}-88 \mathrm{X}-4,113-116 \mathrm{~cm}$. 2. Balcattia sp. A, Sample $122-763 \mathrm{C}-14 \mathrm{R}-3$, $46-49 \mathrm{~cm}$. 3. Balcattia sp. A, Sample 122-763C-14R-3, 46-49 cm. 4. Oligosphaeridium sp. A, Sample 122-763C-31R-3, 48-52 cm. 6. Batioladinium micropodum, Sample 122-762C-79X-1, 14-17 cm. 7, 12. Meiourogonyaulax cf. maculatum, Sample 122-763C-27R-5, 48-50 cm. 8. Oligosphaeridium sp. A, Sample 122-763C-35R-1, 46-49 cm. 9. Tetrachacysta $\mathrm{sp}$. A, Sample 122-763C-17R-1, 48-52 cm. 10, 11. Sentusidinium sp. A, Sample 122-763C-22R-1, 40-43 cm. 13. Tetrachacysta sp. B, Sample 122-762C-89X-5, 19-22 cm. 

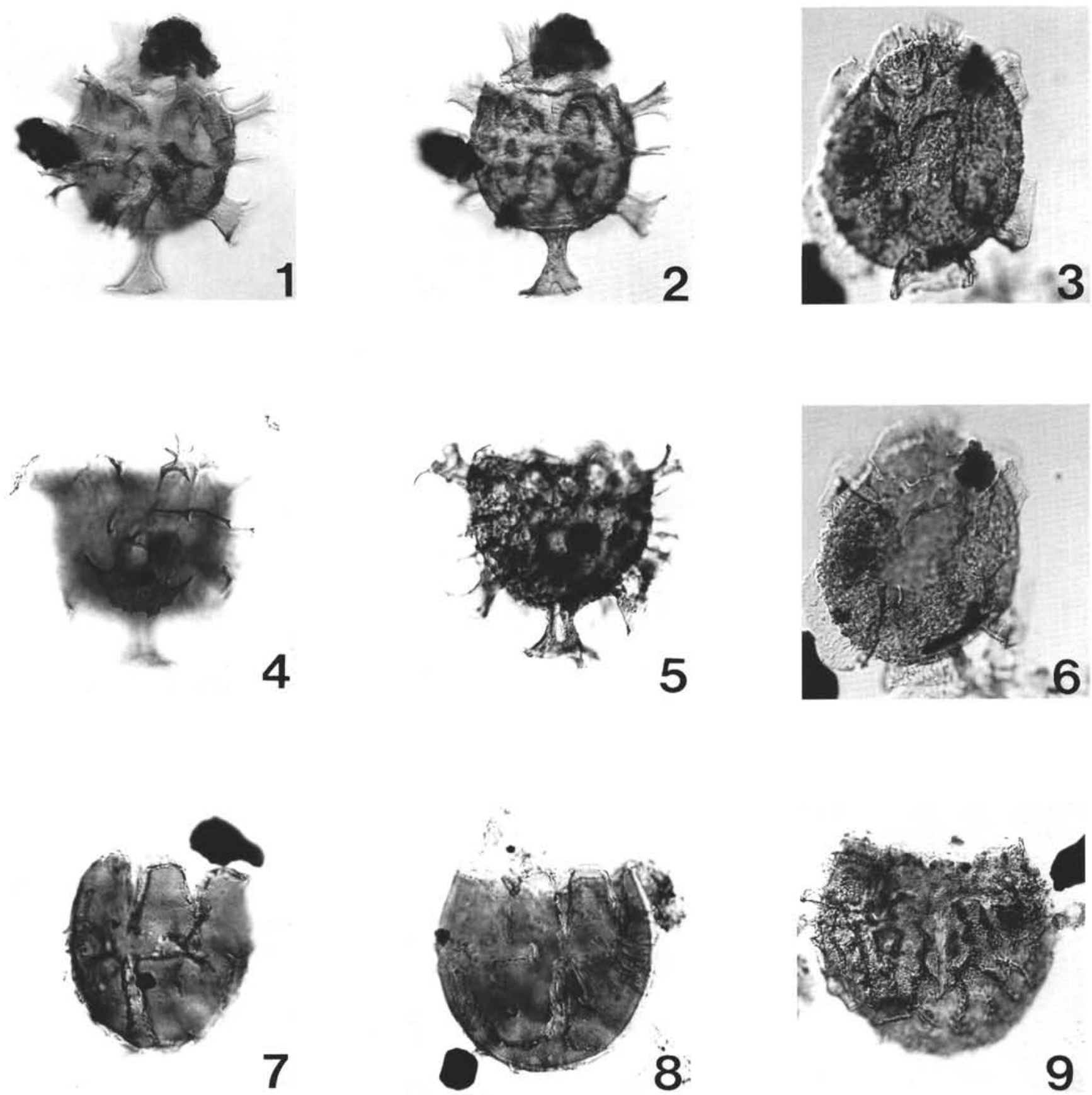

Plate 2. Magnification $\times 500.1$, 2. Amphorula? sp. B, Sample 122-763C-43R-5; 47-51 cm. 3, 6. Amphorula? sp. A, Sample $122-762 \mathrm{C}-88 \mathrm{X}-6$, 127-130 cm. 4, 5. Amphorula? sp. B, Sample 122-763C-42R-1, 47-52 cm. 7. Atlantodinium sp. A, Sample 122-763B-41X-1, 47-49 cm. 8. Atlantodinium sp. A, Sample 122-763B-41X-1, 47-49 cm. 9. Meiourogonyaulax sp. A, Sample 122-763C-41R-3, 48-50 cm. 